\title{
نفقة التعديل الجراحي للزوجة في الشريعة والقانون
}

Doi: $10.23918 /$ ilic2021.34

د. إحسان علو حسين علي اللهيبي

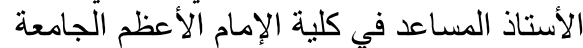

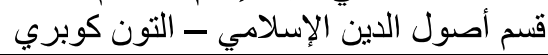

\section{بسم الله الرحمن الرحيم \\ المقدمة المن الرحن}

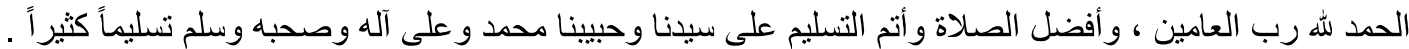

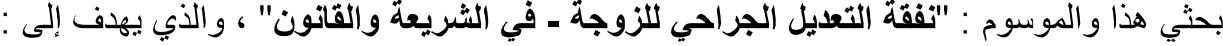

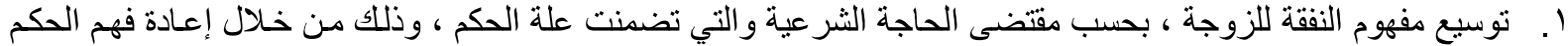

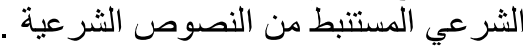

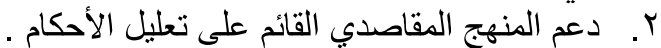

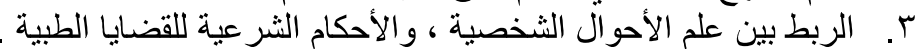

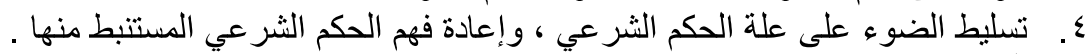

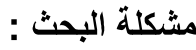

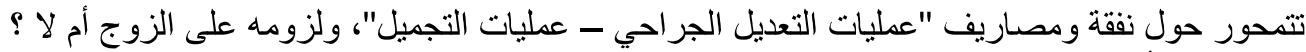

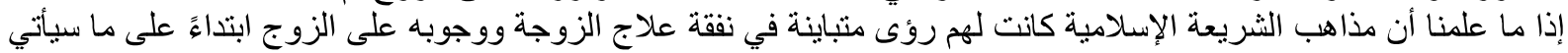

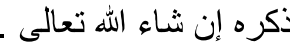

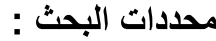

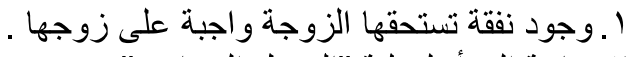

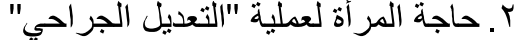

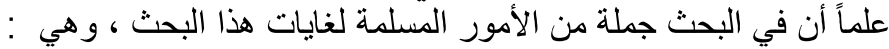

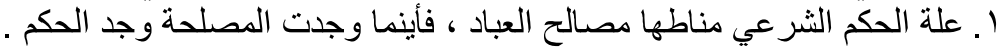

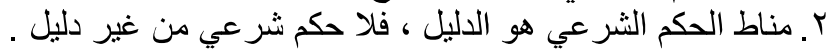

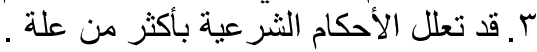

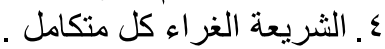

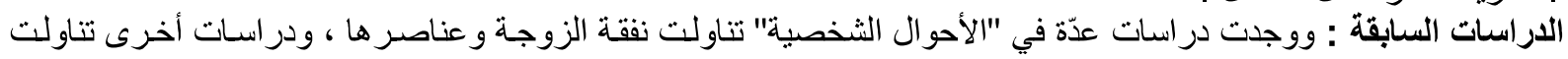

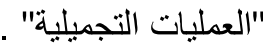

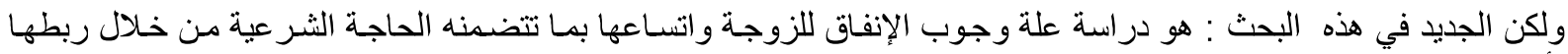

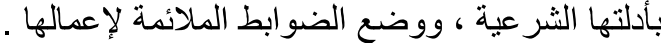
واتبعت في إعداد هذا البحث المنهج التحليلي القائم على الاستقراء غير الإلى الكامل بما يخدم فكرة البحث .

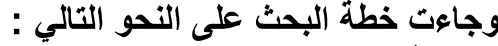

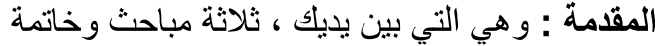

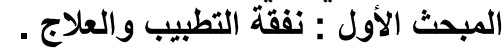
المبحث الثاني : التعديل الجراحي وأقَّامه

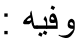

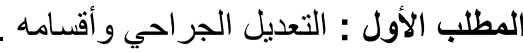

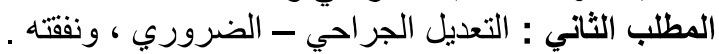

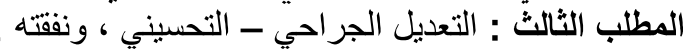

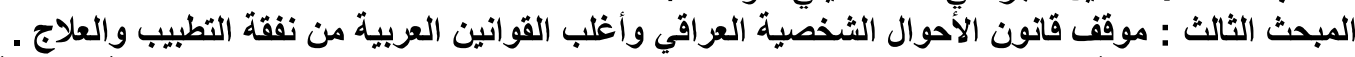

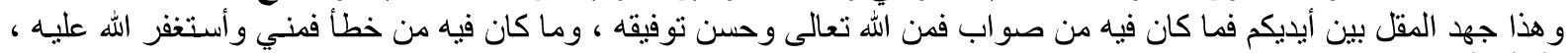

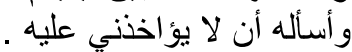
المبحث الأول وآخر دعوانا أن الحمد لله رب العها لعالمين نفقة التطبيب والعلاج

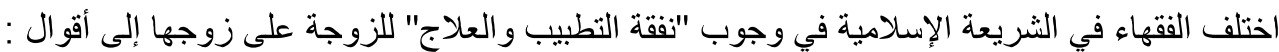
القول الأول : لا يجب على الزوج الجور النطبيب والعلاج لزوجته المريضة 


$$
\text { وإليه ذهب فقهاء المذاهب الأربعة(') . }
$$

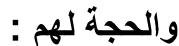

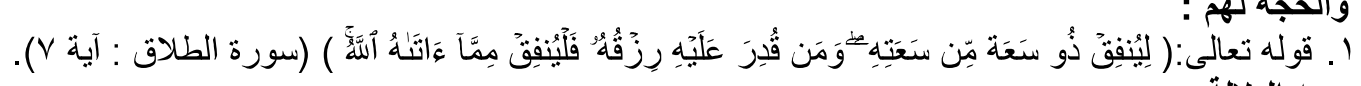

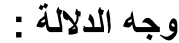
إن الواجب على الـ الزوج هو الإنفاق على ما تقوم به الحياة غالباً "من مأكل ومشرب وملبس" ، وبشكل مستمر حال حياة المرأة

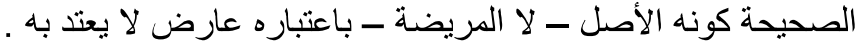

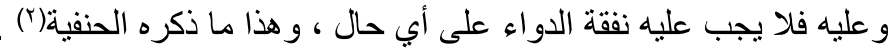

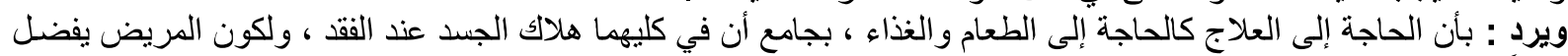

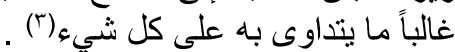

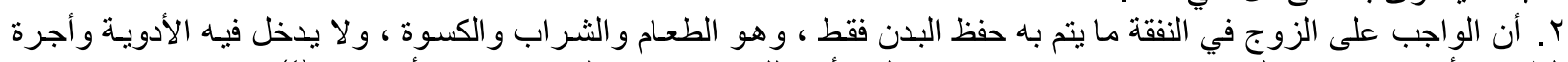

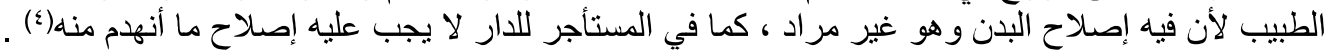

ويرد عليه :

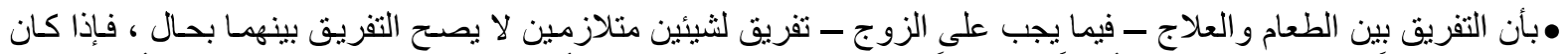

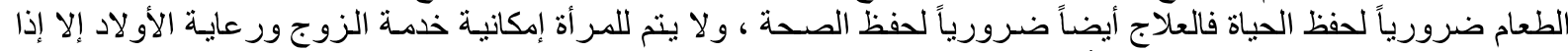

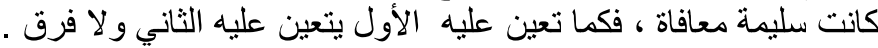

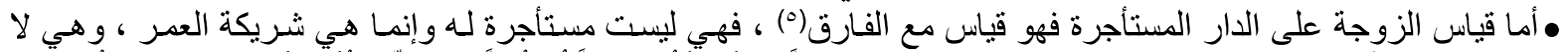

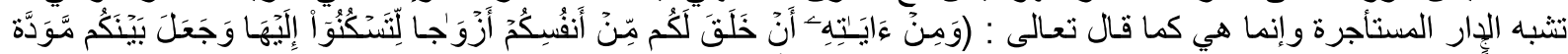

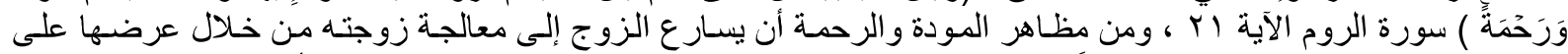

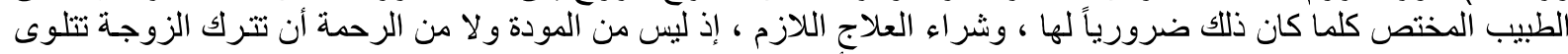

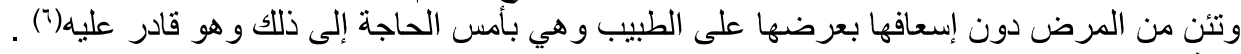

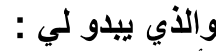

بأن مأ ذكره الفقهاء الأجلاء من أدلة ، هي في حقيقتها أدلة تقريضية لواقع ، واجتهاد الققهاء مبني على أمر قائم في عصر هم ،

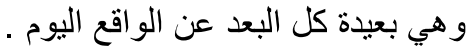

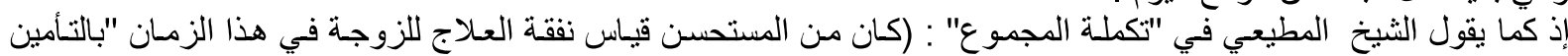

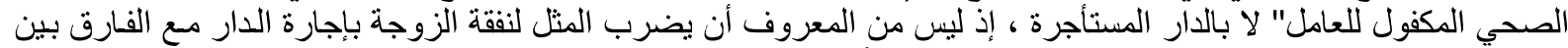

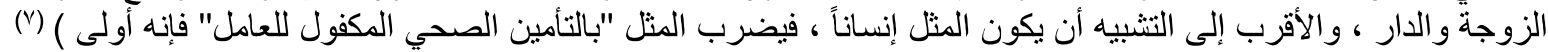

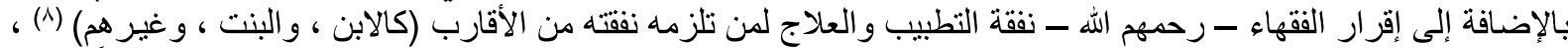

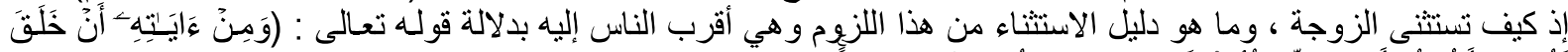

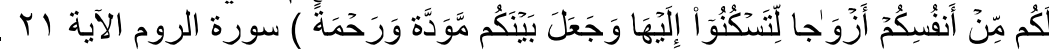

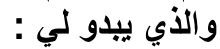
أن الأليل الأوحد للفقهاء رحمهم الله على ما ذهبوا إليه في عدم الوجوب هو : "العرف" ، وهو ما كان متعارفاً عليه وقائم فيما

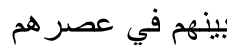

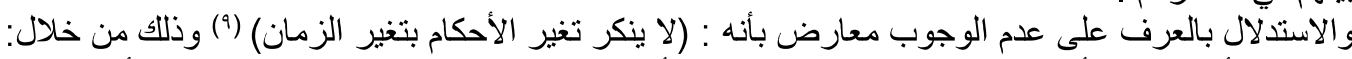

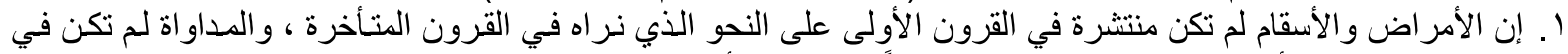

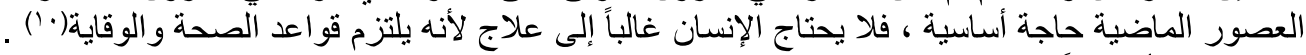

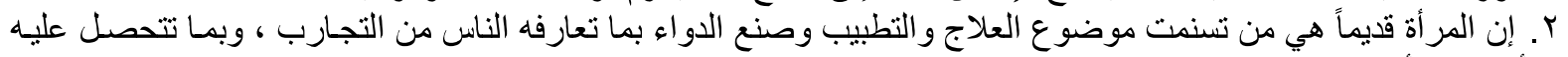

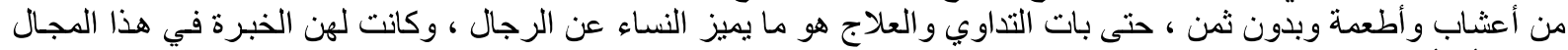

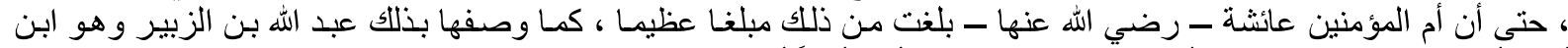

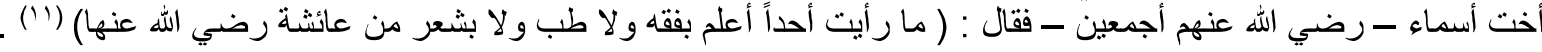

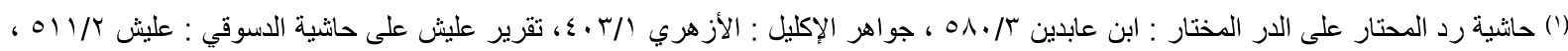

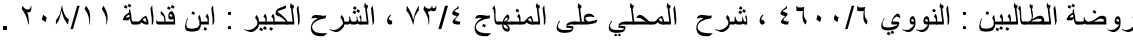

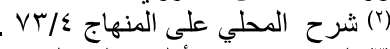

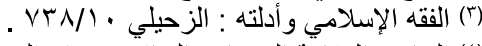

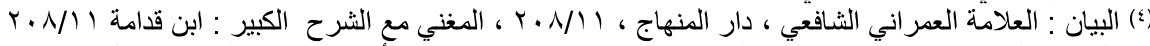

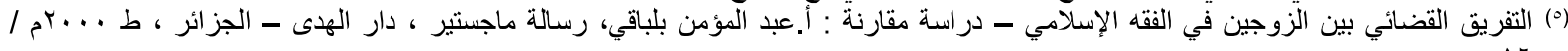

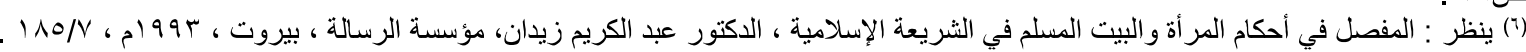

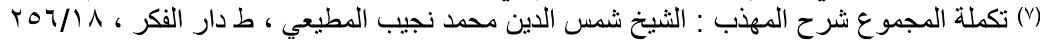

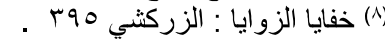

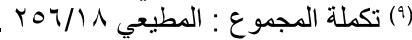

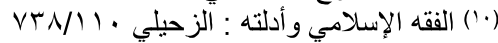

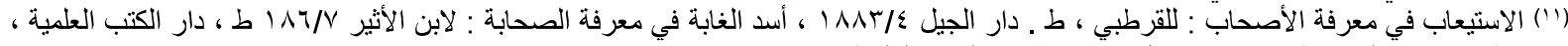

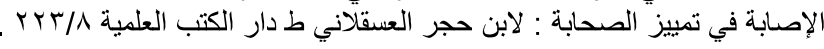




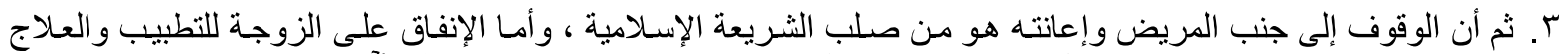

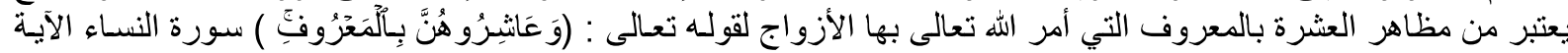
19 ويتساءل الدكتور وهبـة الزحيلي : هل من حسن المعاشرة أن يستمتع الزوج بزوجته حال الصحة ، ثم يردها إلى أهلها حسال

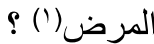

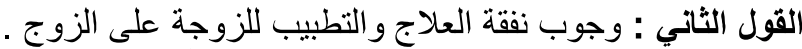

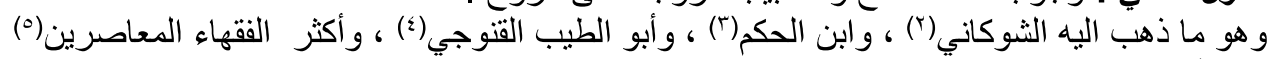

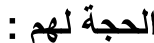

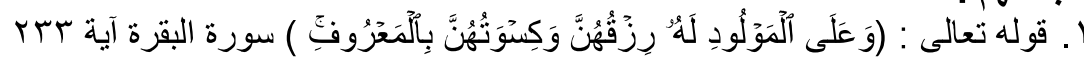

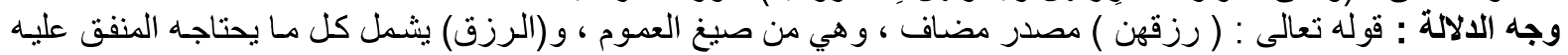

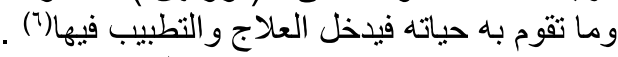

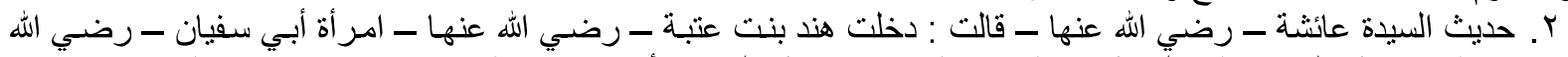

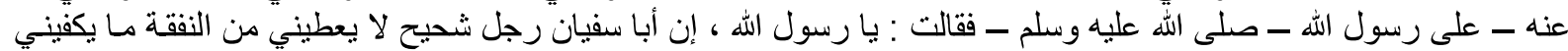

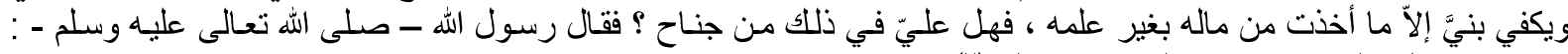

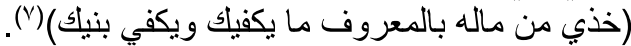

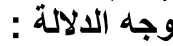

لفظ : (ما يكفيك) عامة باعتبار لفظ ما ، والمقصود كفاية المرأة على زوجها ، وهي تشمل العلاج عند المرض للحاجة إليه(^)

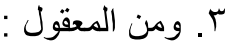

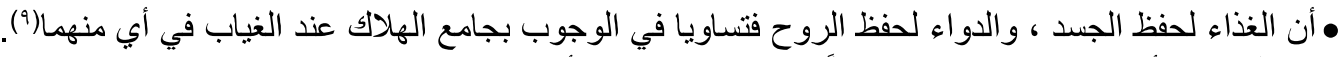

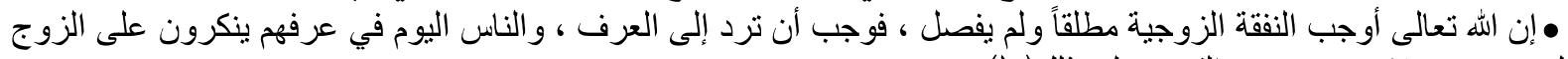

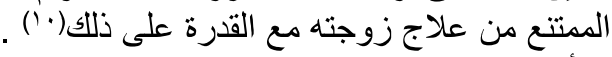

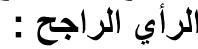

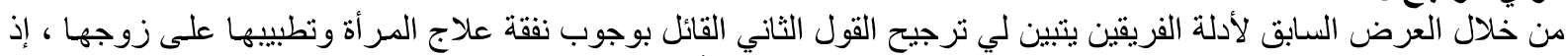

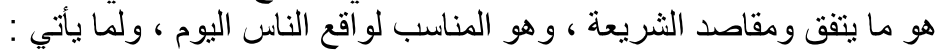

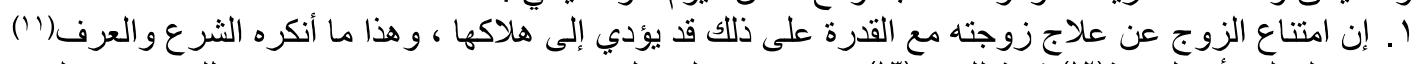

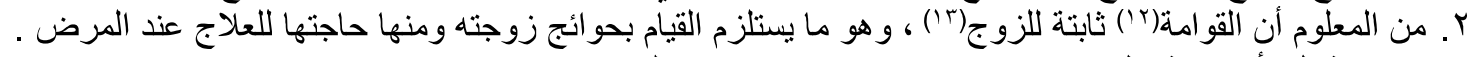

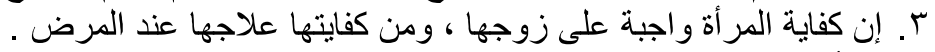

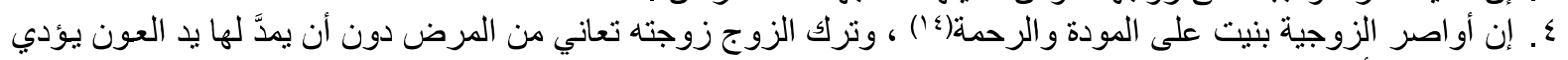

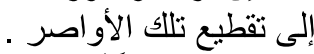

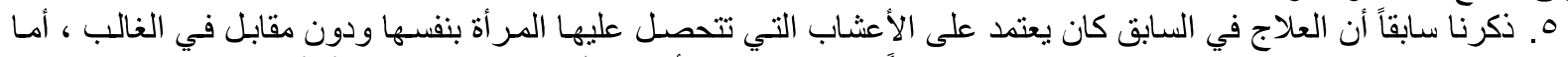

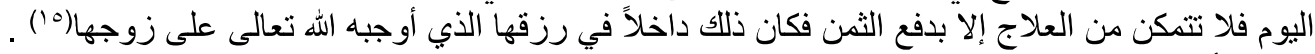

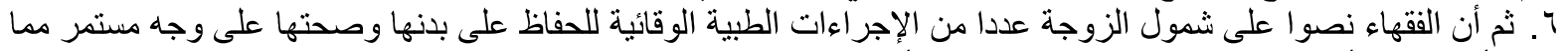

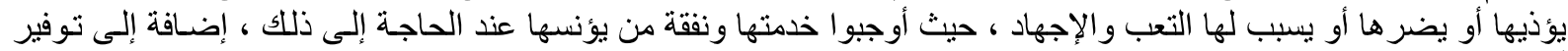

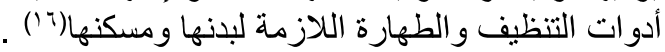

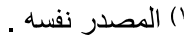

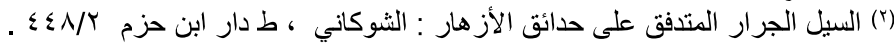

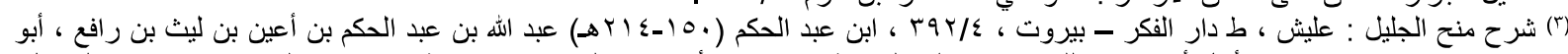

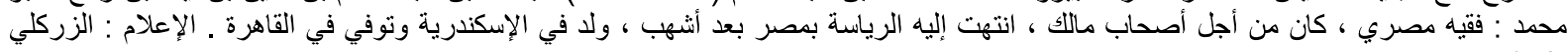
$11 \mathrm{~T} / \mathrm{T}$ (1)

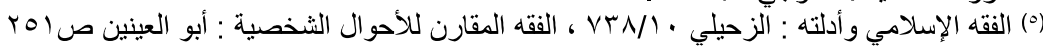

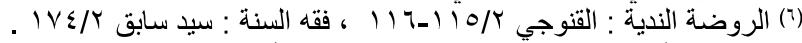

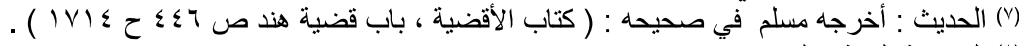

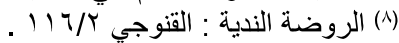

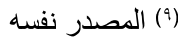

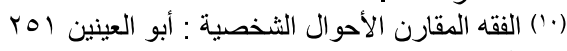

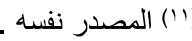

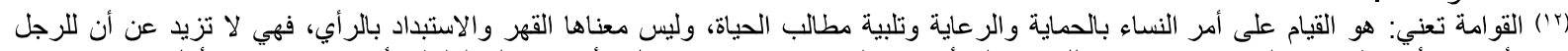

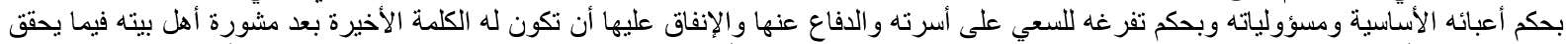

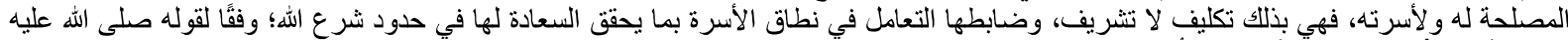

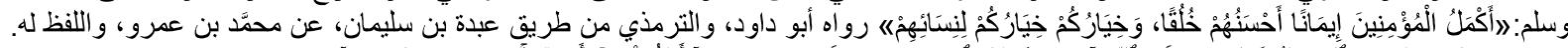

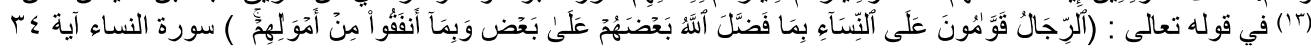

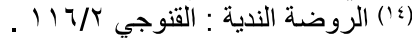

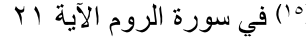

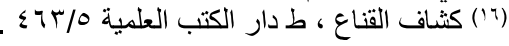


وفي هذا حجة داحضة للوجوب ، فالفقهاء الذين يوجبون "نفقة المؤنسة والخادمة" والذي فيه سلامة الزوجة بطريقة غير مباشرة ،

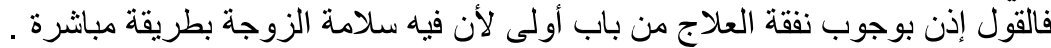

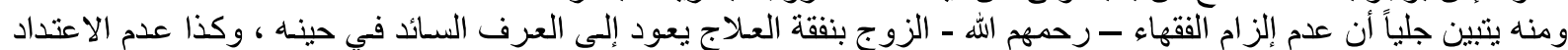

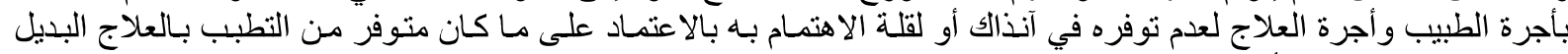

\section{التعديل الجراحي ، وأقبشامه الثاني}

المطلب الأول : ماهية التعديل الجراحي ، وأقسامه

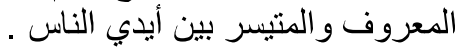

ويتضمن : (20)

ماهية " التعديل الجراحي" : التعديل الجراحي أو "الجعليات التجميلية" : مصطلح حديث ويعني : الجراحات التي تجري لتحسين منظر جزء من أجزاء الجسم

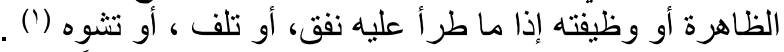

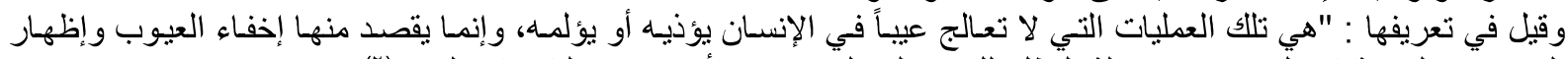

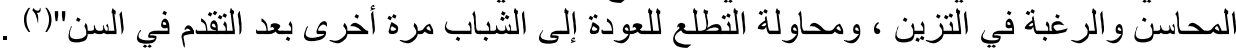

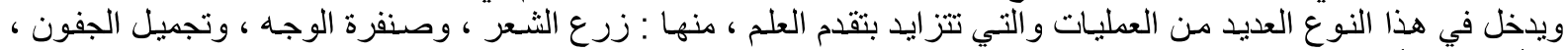

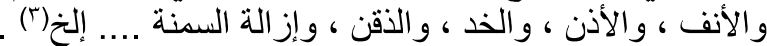

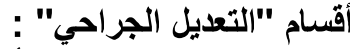

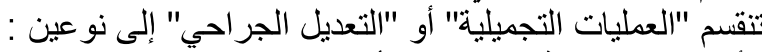

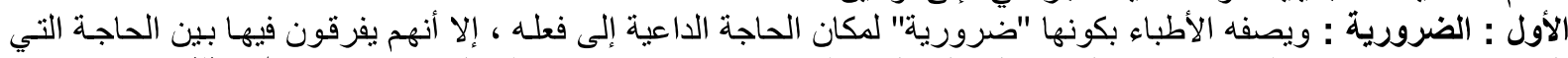

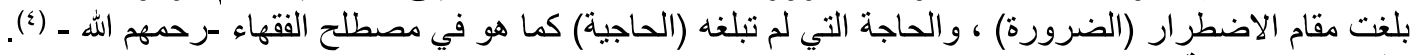

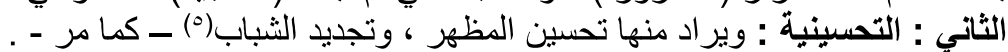

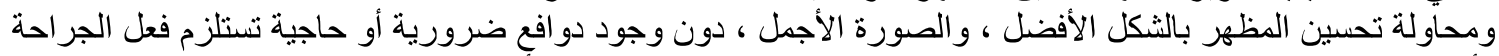

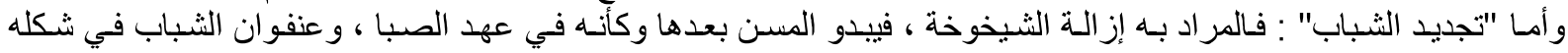

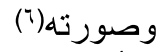
ولأ همية هذا التقسيم سوف نورد لكل منهما مطلباً مستقلاً نوضح من خلاله حكم نفقة هذه العمليات لكل منهما .

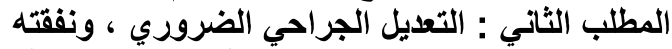

ذكرنا في المطلب الأول ماهية "التعديل الجراحي الضّروري" ، وذكرنًا بأن هذا الوصف الوصف أطلق عليها لكونها "ضرورية" للحاجة

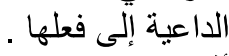

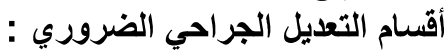

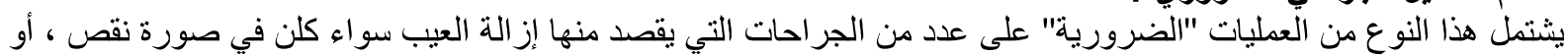

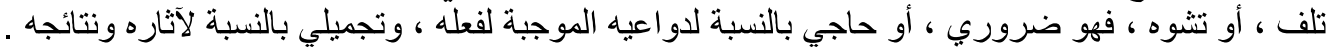

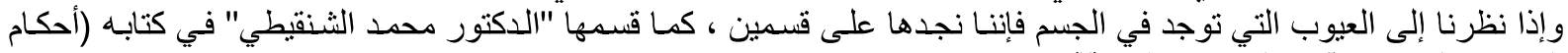

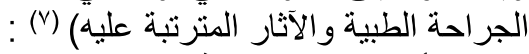

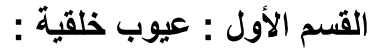

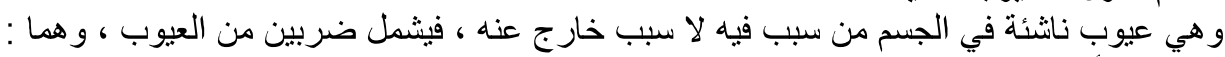

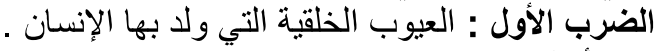

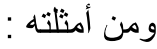

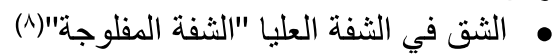

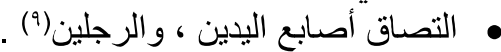

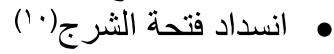
• • شذوذ الحويضة الخلقي ومن أهمها (ازدواج حويضة الكلية) (1')

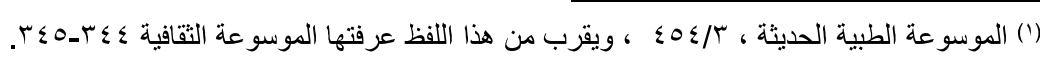

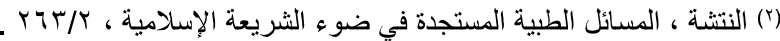

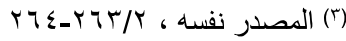

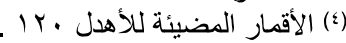

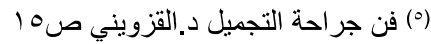

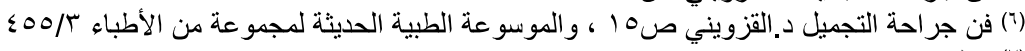

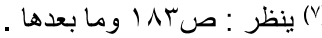

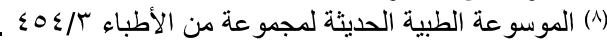

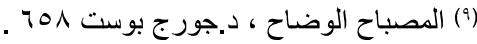

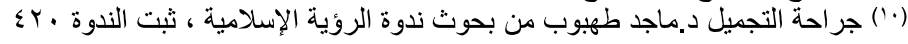

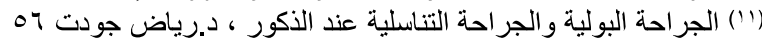


• شذوذ الحالب الخلقي (الازدواج الحالبي ، ارتكاز الحالب الهاجر ، الحالب خلف الوريد الأجوف ، الحالب العرطل الخلقي ،

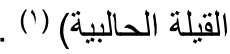

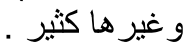
الضرب الثاني : العيوب الناشئة من الآفات المرضية التي تصيب الجسم .

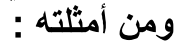

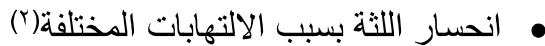

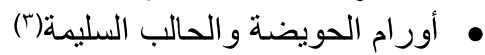

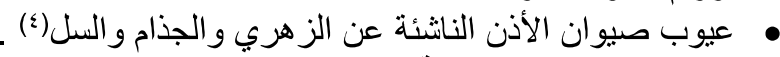
القسم الثاني : عيوب مكتسبة : الأبن و وهي العيوب الناشئنة بسبب من خارج الجسم كما في العيوب و التشوهات الناشئة من الحوادث والحروق .

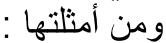

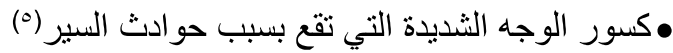

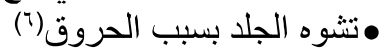

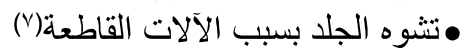

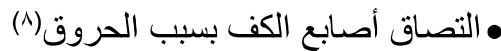

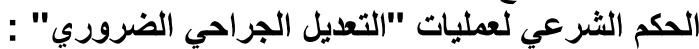
هذا النوع من الجر احة الطبية وإن كان مسماه يدل على تعلقه بالتحسين والتجميل إلا أنه توفرت فيـه الدوافع الموجبة للترخيص

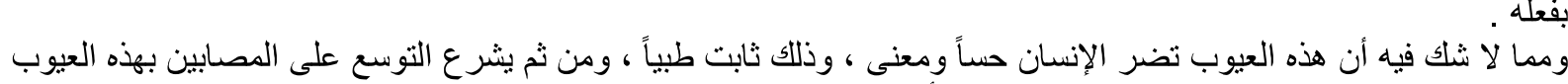

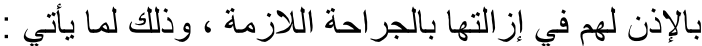

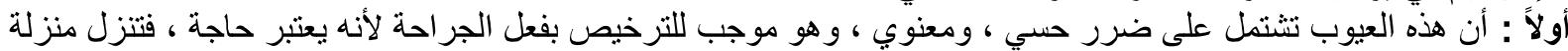

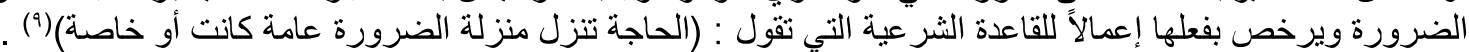

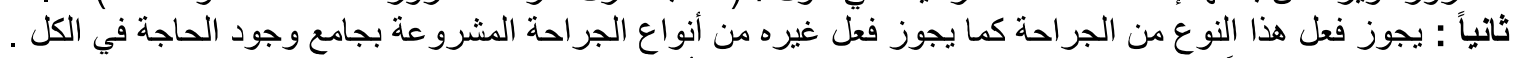

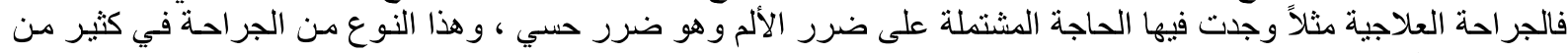

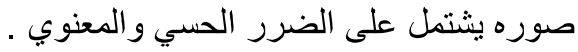

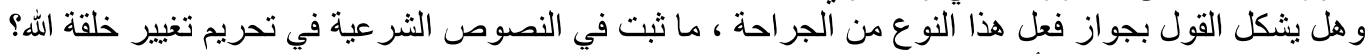

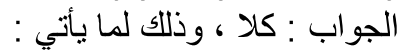

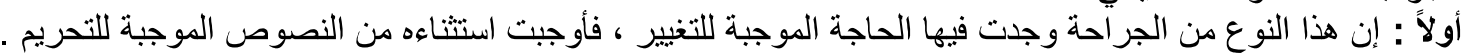

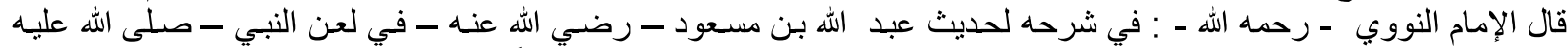

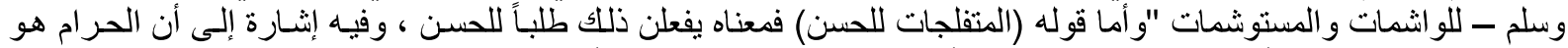

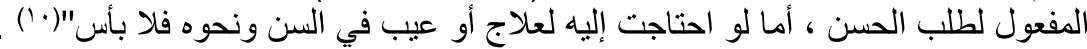

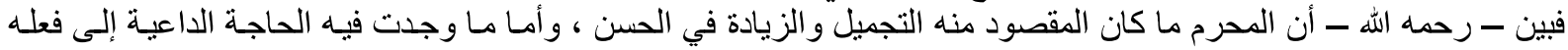

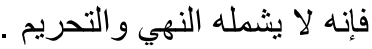

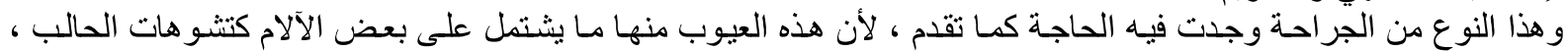

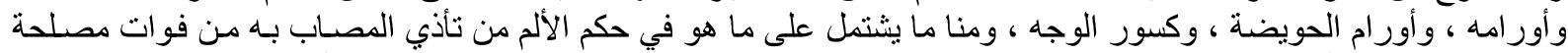

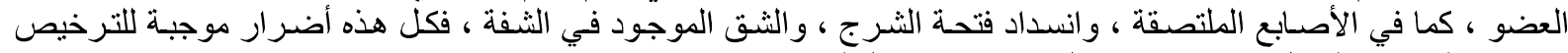

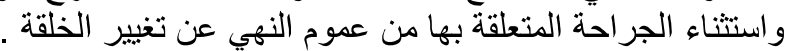

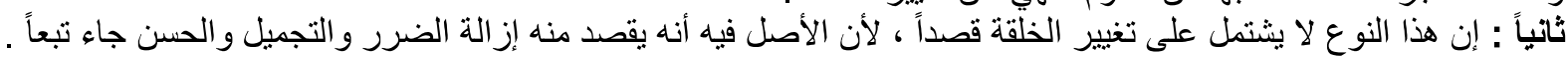

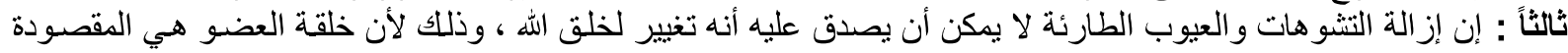

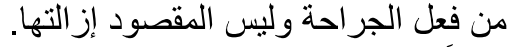

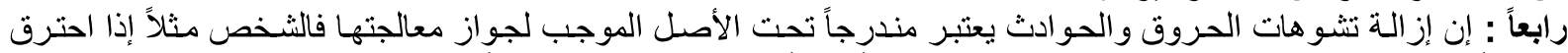

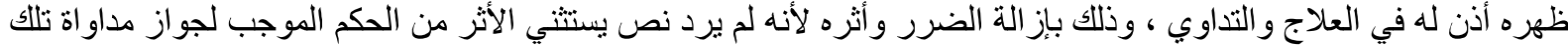

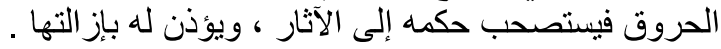

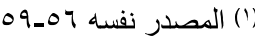

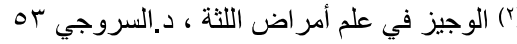

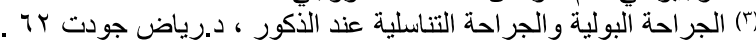

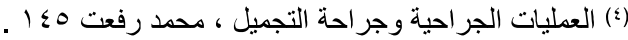

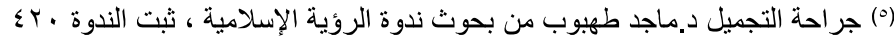

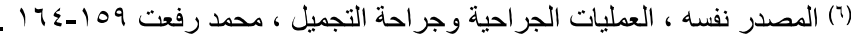

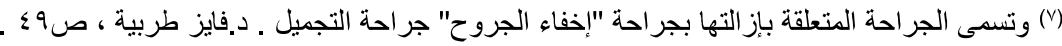

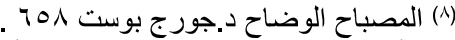

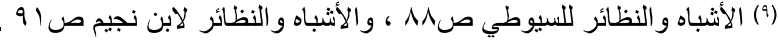

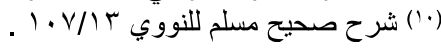




\section{حمم نفقة التعديل الجراحي الضروري :}

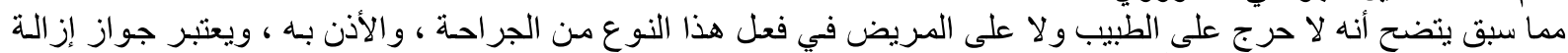

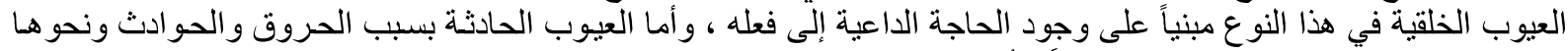

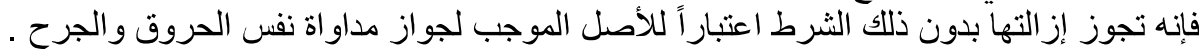

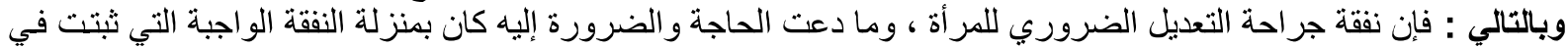

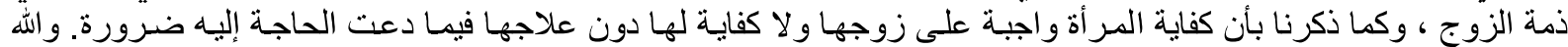

\section{المطلب الثالث : التعديل الجراحي التحسيني ، ونفقته}

$$
\text { تعالى أعلم . }
$$

تتقسم عمليات "التعديل الجر احي التحسيني" إلى قسمين :

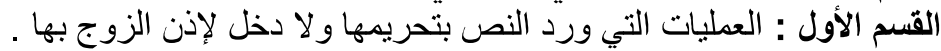

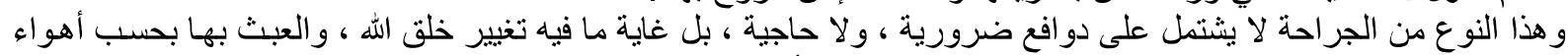

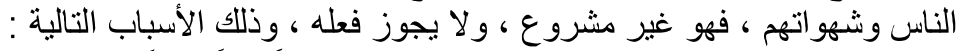

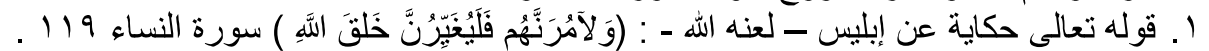

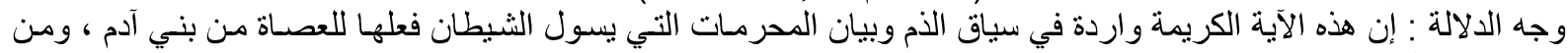

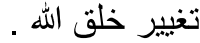

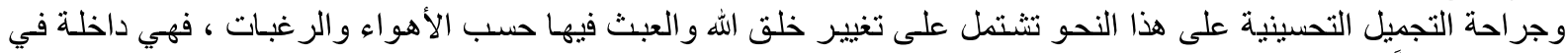

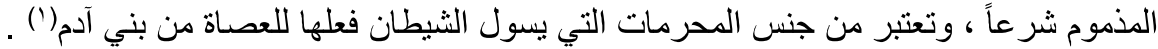
و وعليه : فبانتفاء الحاجة الداعية وعدم وجود ضرورة إلى هذه الجراحة فإنها يحرم فعلها و الإقدام عليها من فبل الطبل الطبيب الجراح ،

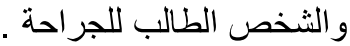
وتعتبر الدوافع التي يتعذر بها من يفعله من كون الثخص يتألم نفسياً بسبب عدم تلبية رغبته بفعل هذا النوع من الجراحة غير

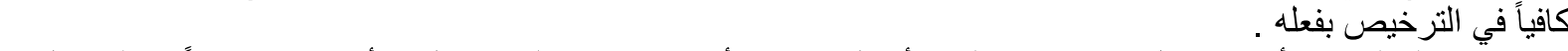

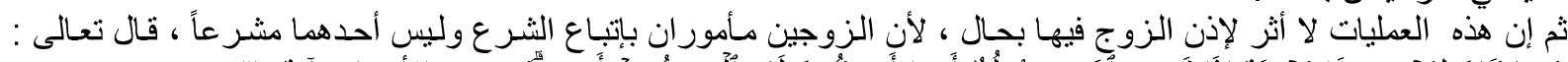

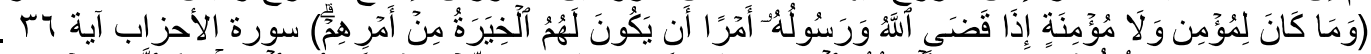

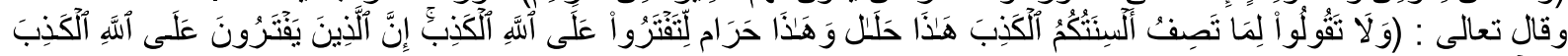

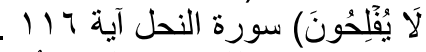

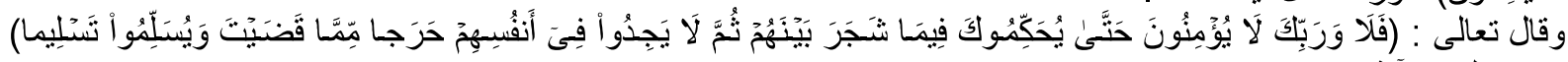

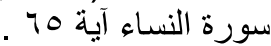

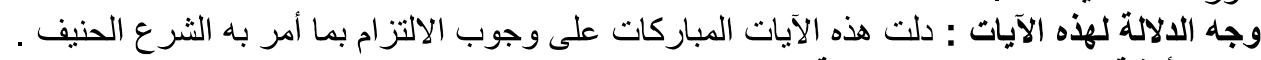

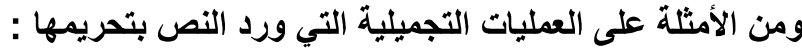

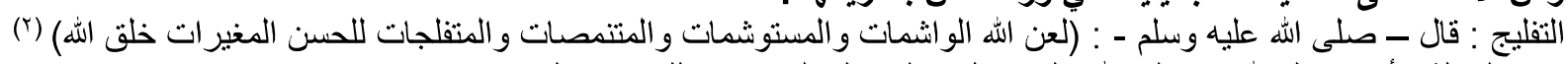

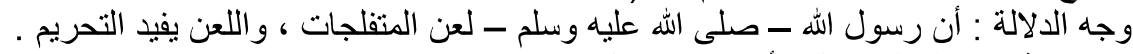

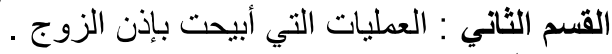

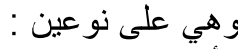

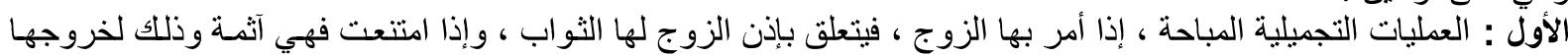

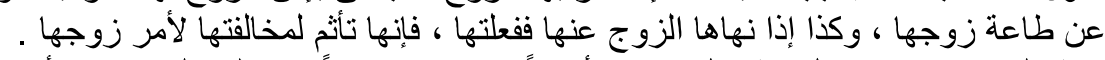

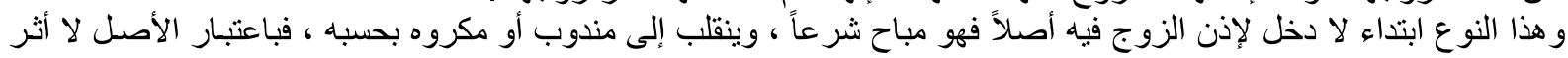

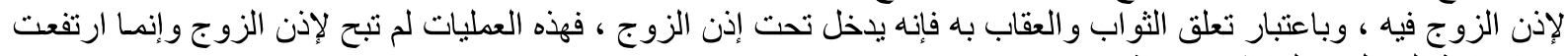

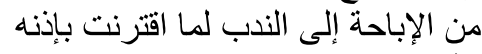

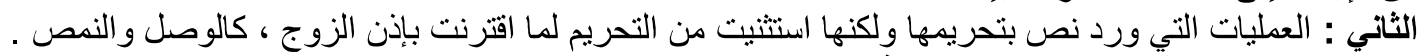

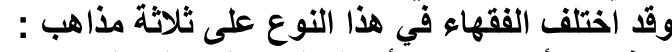

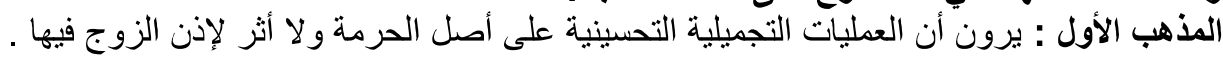

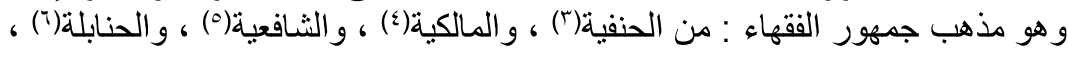

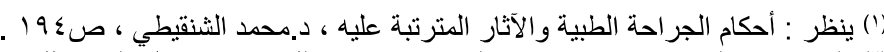

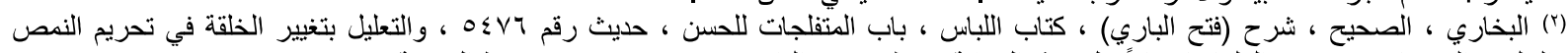

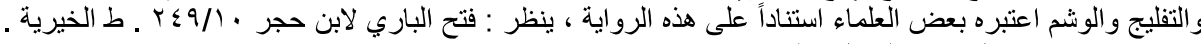

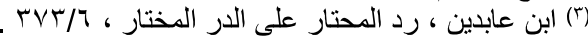

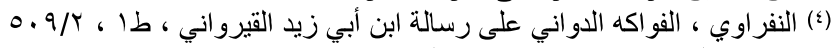

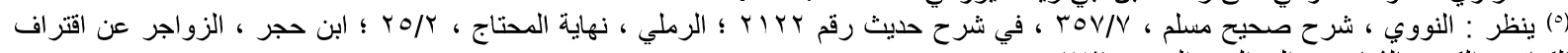

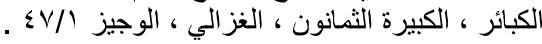

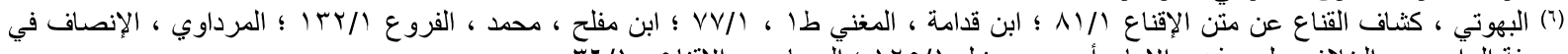

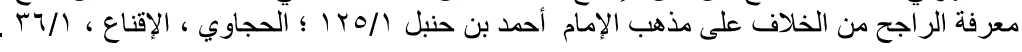




$$
\text { والزيدية(') ، والإباضية(r) ، و والظاهرية وغير هم(r) . }
$$

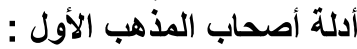

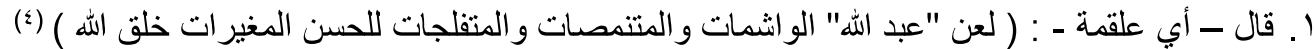

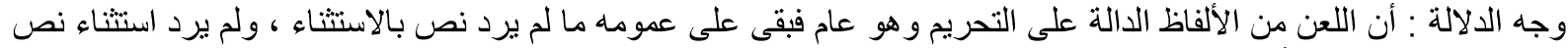

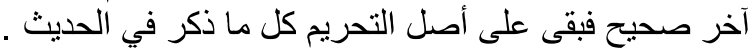

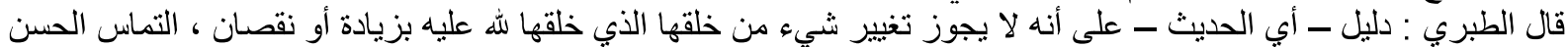

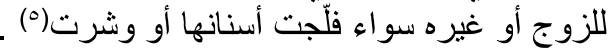

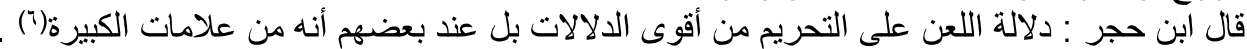

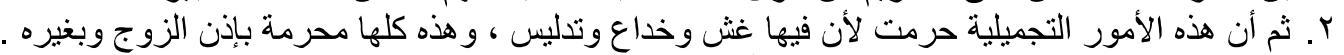

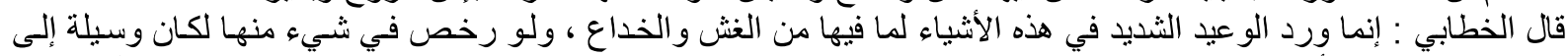

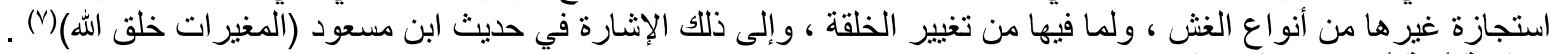

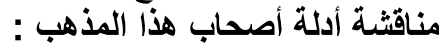
ا ـ إن أحاديث اللعن جاءت معللة بعلل منها (طلب الحسن) و (تغيير خلق الله) وفي روايات أخرى ذكرت علل منها : (الزور

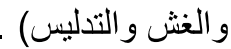

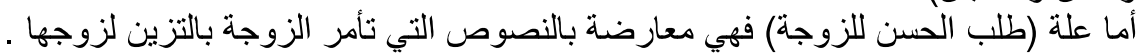

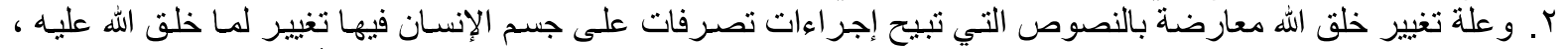

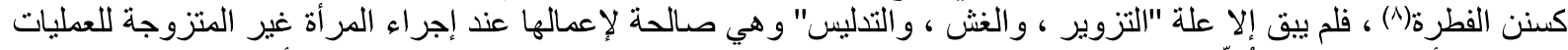

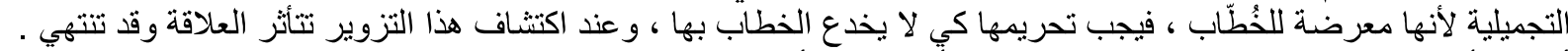

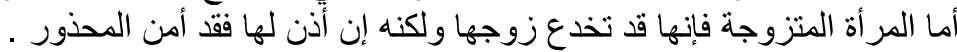

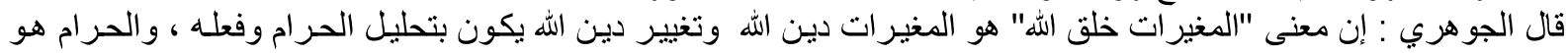

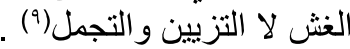

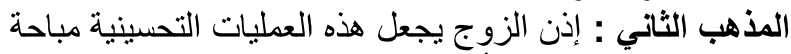

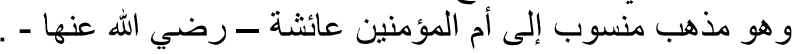

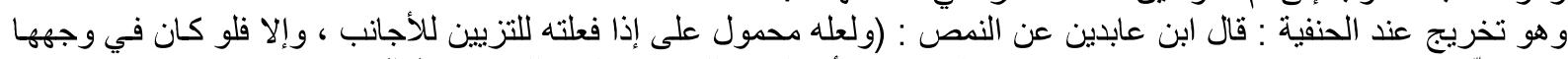

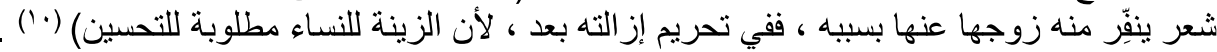

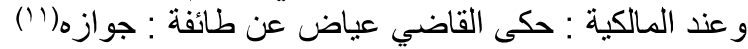

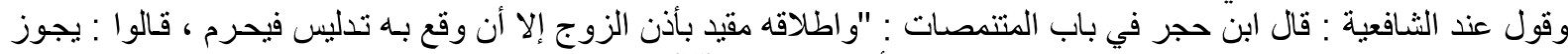

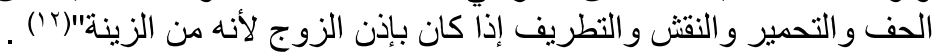

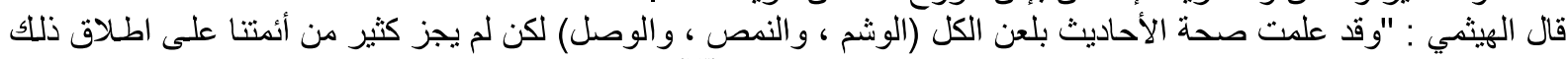

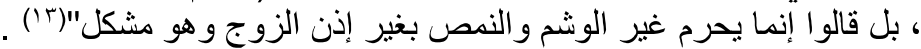

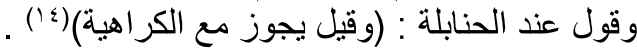

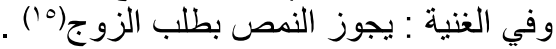

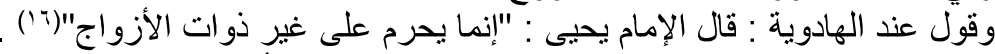

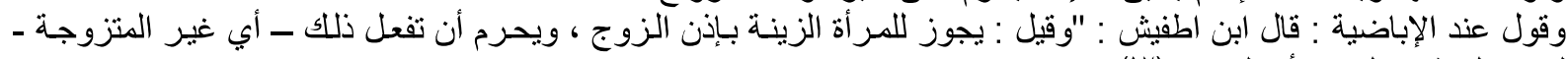
لتو هم الخطاب الحسن أو الثباب"(v)

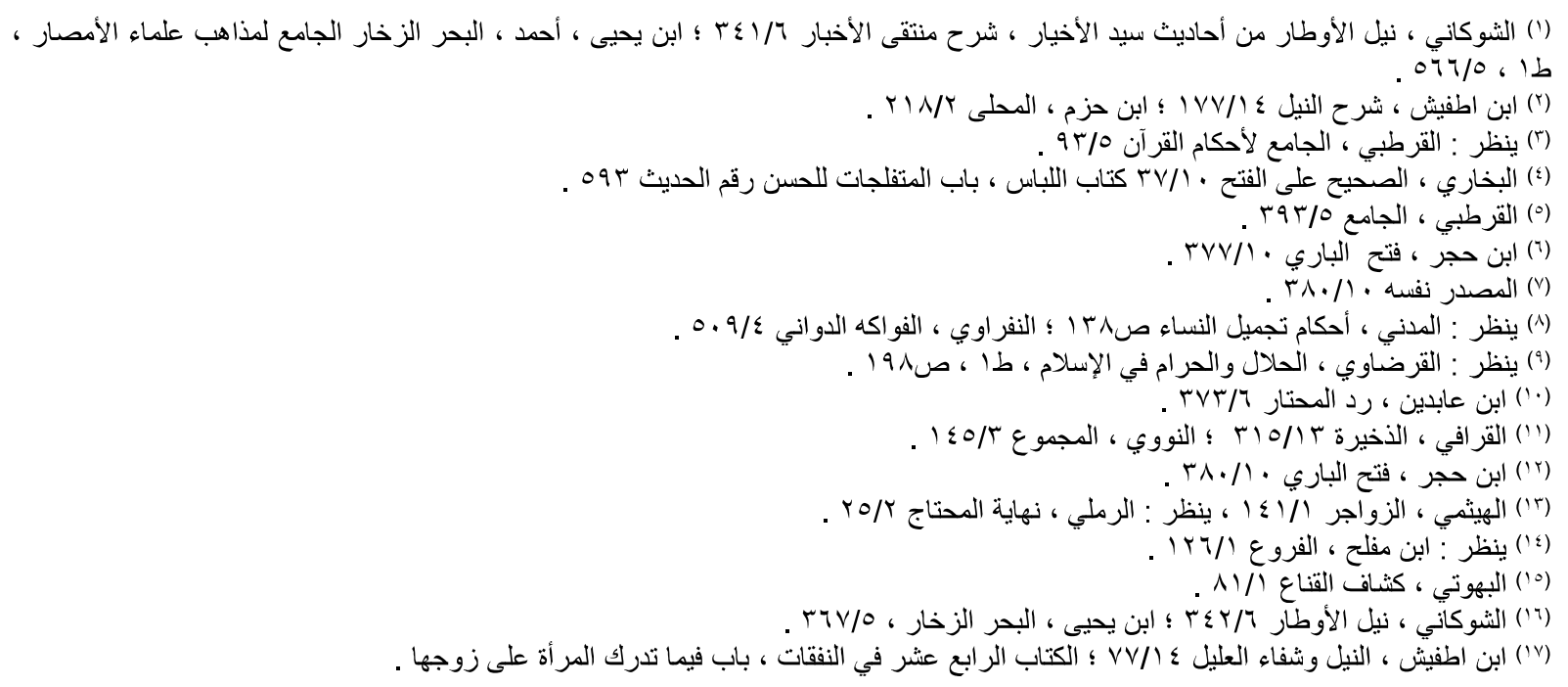


أدلة أصحاب هذا المذهب :

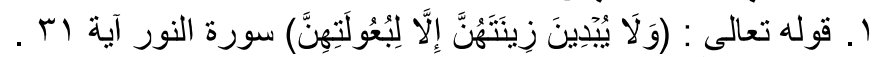

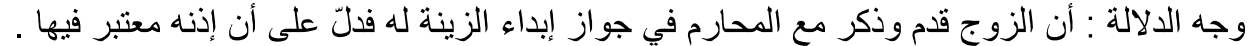

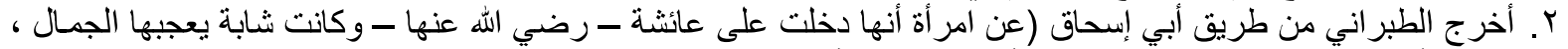

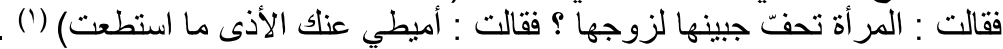

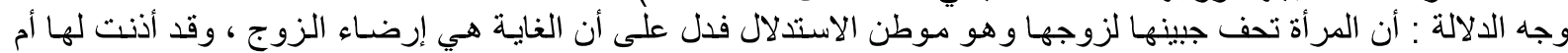

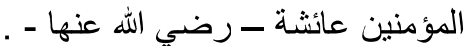

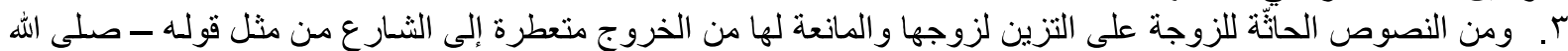

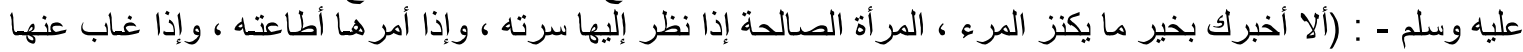

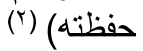

وقولهـ صلى الله عليه وسلم - : (تنكح المرأة لأربع : لمالها ، ولحسبها ، ولجمالها ، ولدينها ، فاظفر بذات الدين تربت يداك) (ّ) . وجه الدلالة بهذه النصوص النهو : إن إذن الزوج لزوجته في التجمل له ولو بإجر اء العمليات المختلفة يحقق مقصداً شـرعياً جاءت بـه هذه النصوص و أمثالها فدل

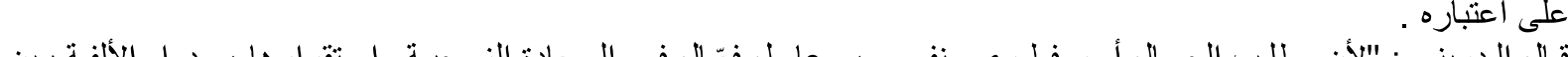
قـال الدريني : "لأن مطلب الجمـال أمر فطري ونفسي ، وعامـل فعَّال في السـعادة الزوجيـة واستقر ارها ، ودوام الألفة بين

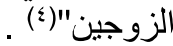
وقال : "إن من عناصر الخيرية في النساء : الجمال وحسن السمت والنظافة والأناقة، لأنها مظاهر مادية حسية هي مناط السرور

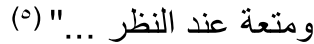

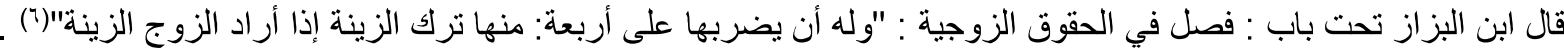

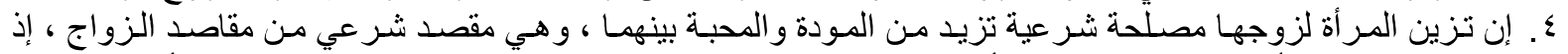

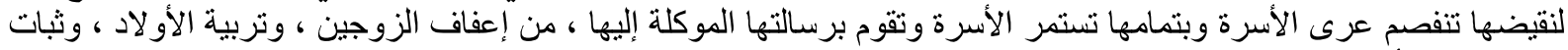

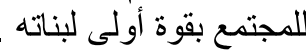

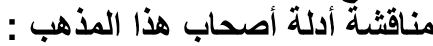

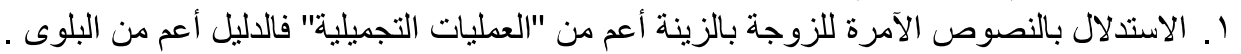

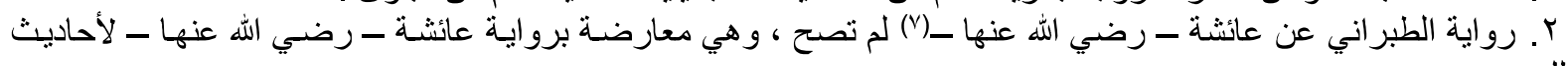

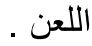

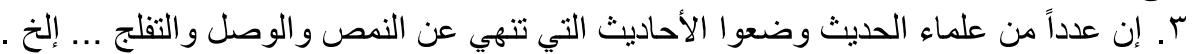

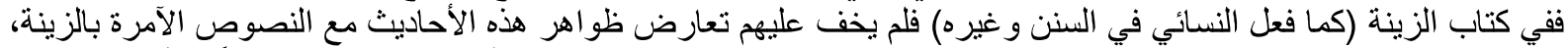

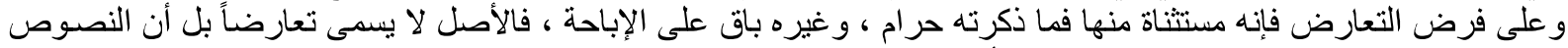

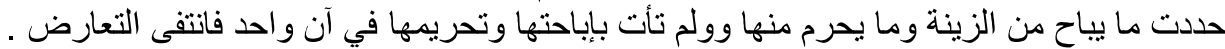

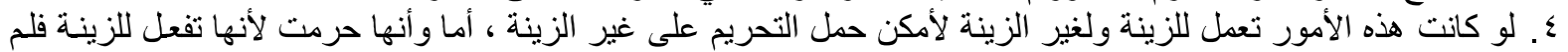

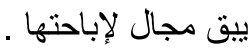

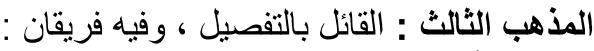

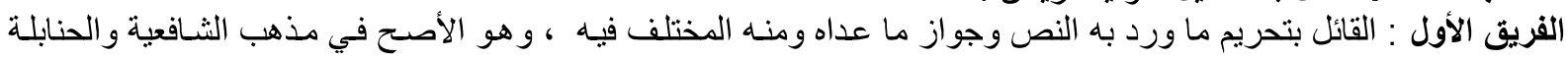
الفريق الثاني : التحريم إذا كان يقع بهذه العمليات خداع وتدليس أو تغيير لخلق الله وإلا فلا ، ذكره اليوسي ـ ت r ـ 11 اهـ - .

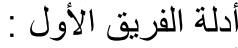

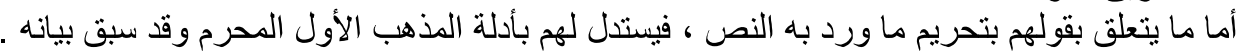

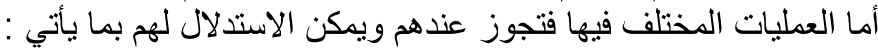

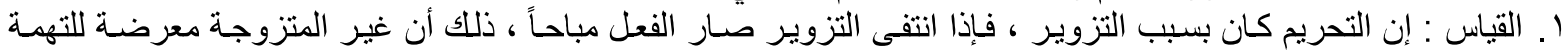

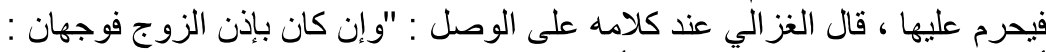

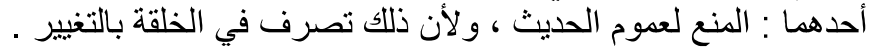

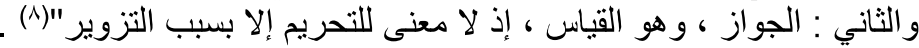

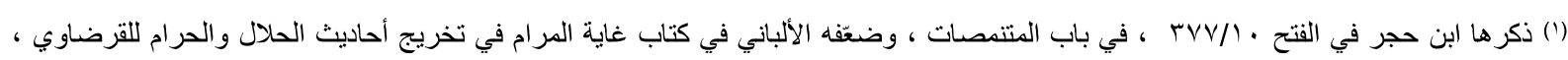

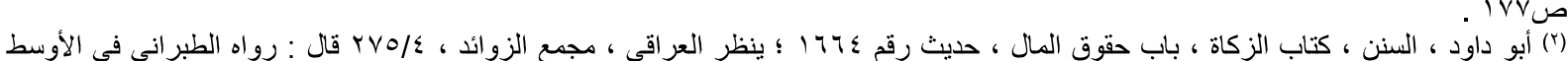

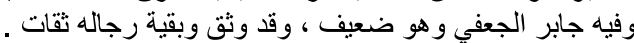

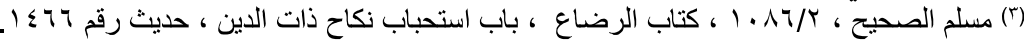

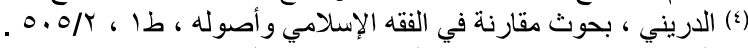

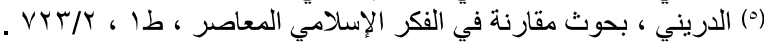

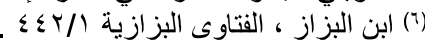

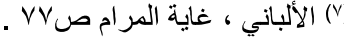

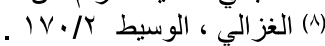


قال اليوسي : "وأما التفريق بين شعر الآدمي وغيره فلا يظهر له وجه في باب التغيير ، و وإنما يظهر في التدليس"(') .

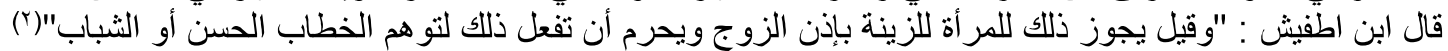

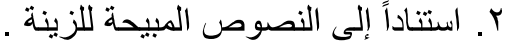

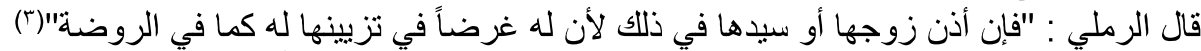

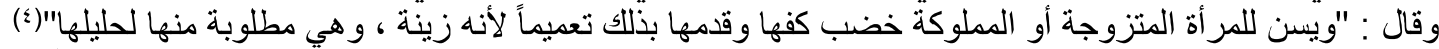

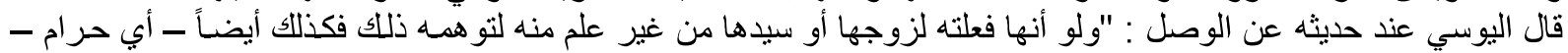

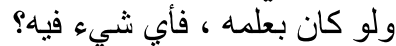
و إنما هو حينئذ نزين يحسن به به نظر ها عند صاحبها ، كالاكتحال و التسوك ، وربما كان تركه تشويها وتقبيحاً يكون سبباً للبغضساء

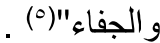
كـ. العرف : جاء في الإنصاف : "ووجّه في الفروع وجهاً بإباحة تحمير ونقش وتطريف بإذن الزوج فقط ، وعمل الناس على

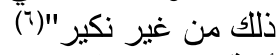
أدلة القريق الثاني : القائل "بتحريم العمليات التجميلية التي فيها تغيير لخلق الله أو خداع أو تدليس و إلا فلا" .

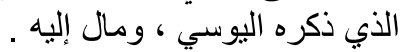

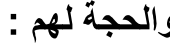
ا. ـورود الاحتمال في فهم النصوص ، قال اليوسي : "وينبغي أن يعلم أن تحقيق المسألة ـ وصل الثعر - إنما يثبت بالنظر إلى أمرين : (الورد

الأول : ألفاظ الأحاديث وما تدل عليه مطابقة أو التزاماً.

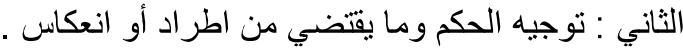

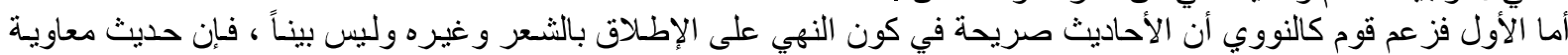

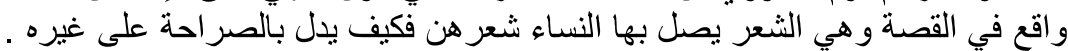

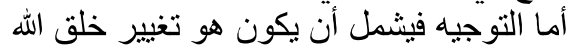

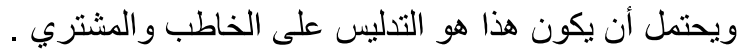

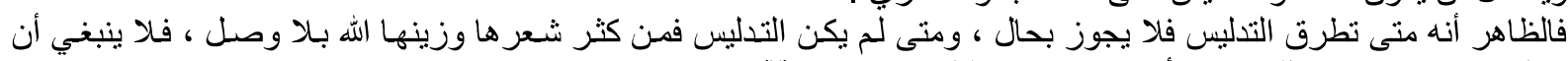

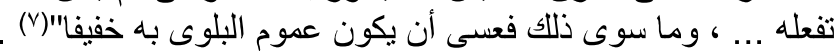

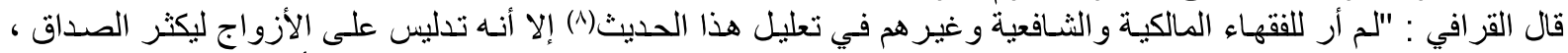

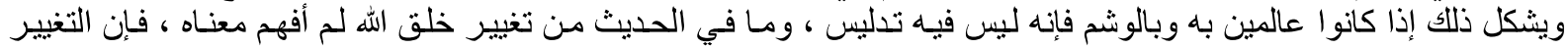

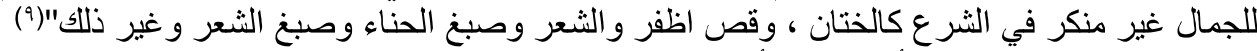

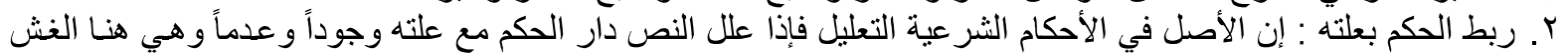

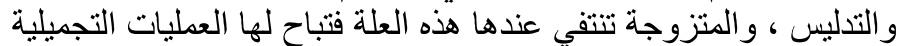

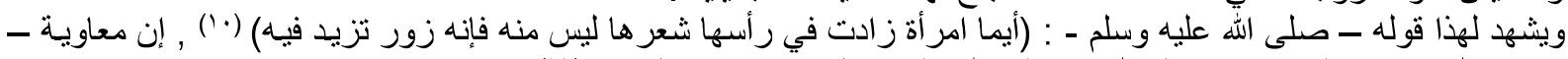

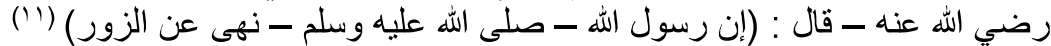

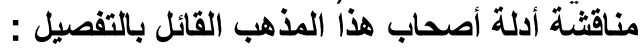

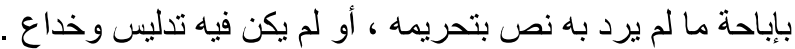

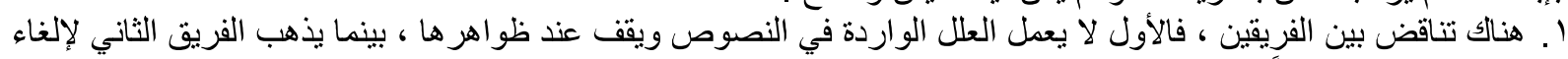

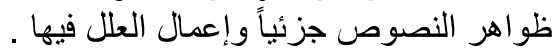

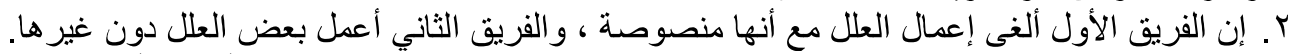

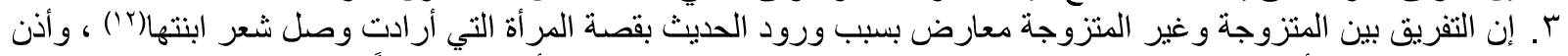

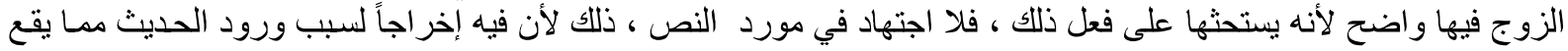


والأي يبدو لي ترجيحه : إنيات

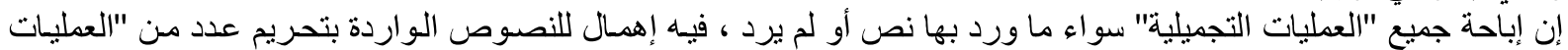

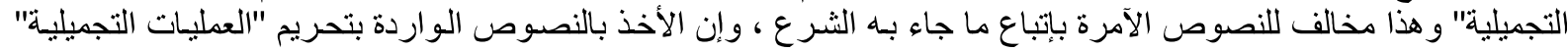

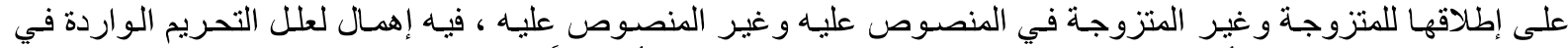

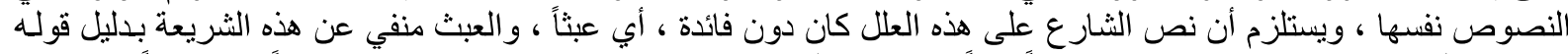

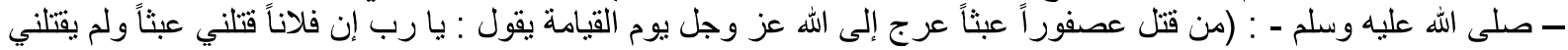

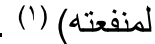

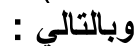

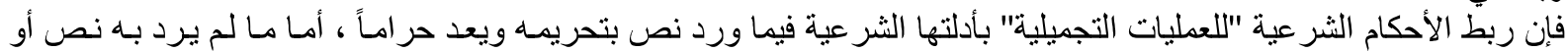

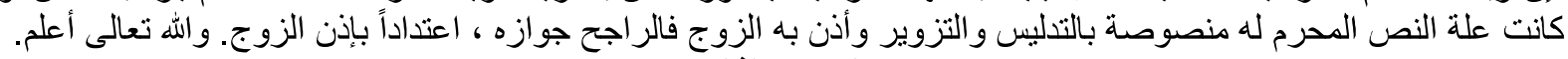

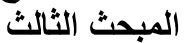

موقف قانون الأحوال الثخصية العراقي وأغلب القوانين العربية من نفقة "التطبيب والعلاج" التواج

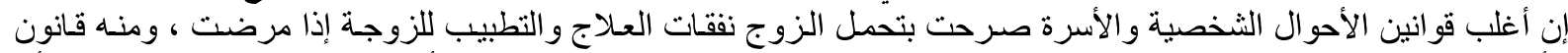

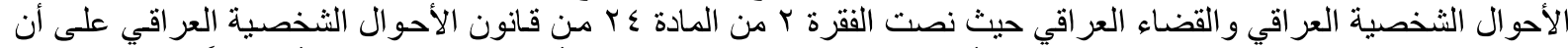

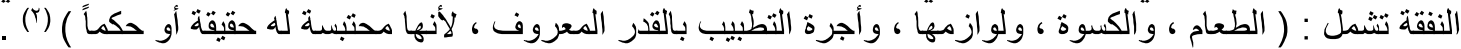

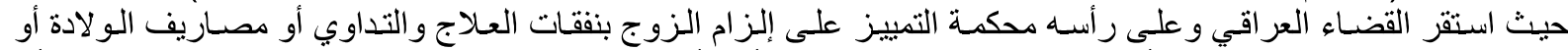

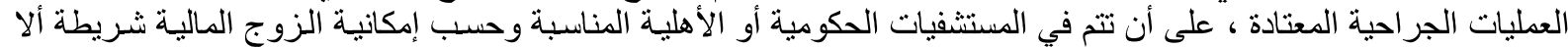

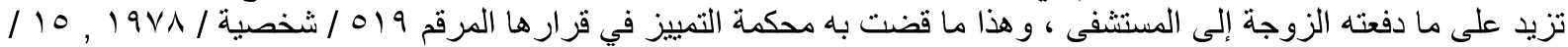

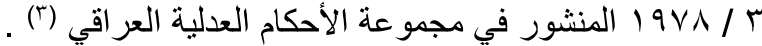

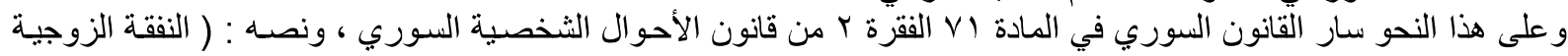

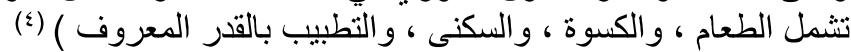

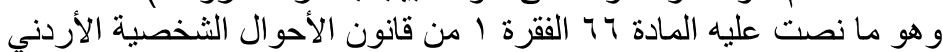

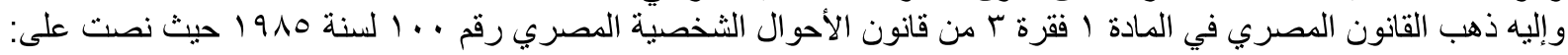

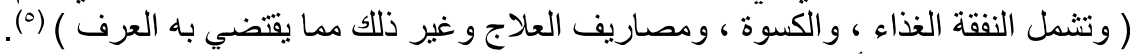

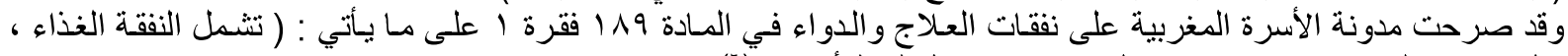

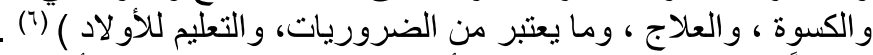

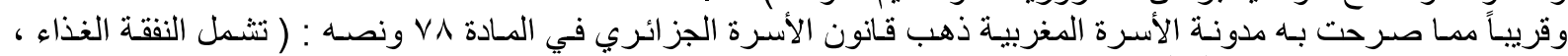

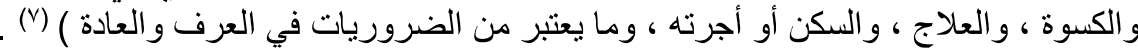

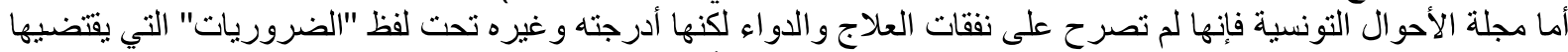

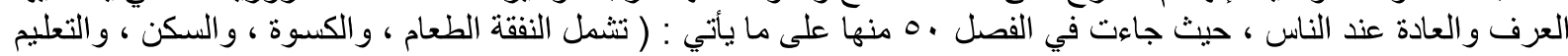

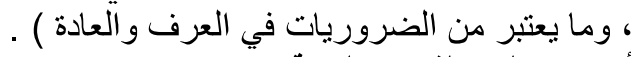

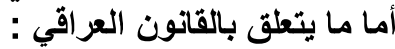

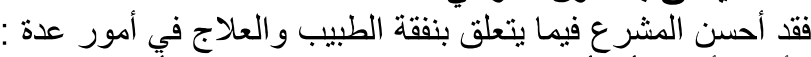

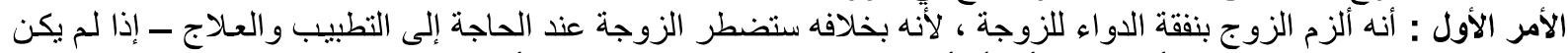

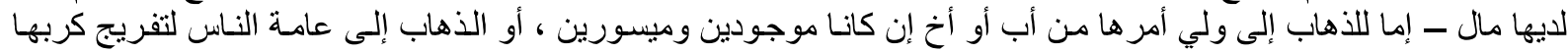

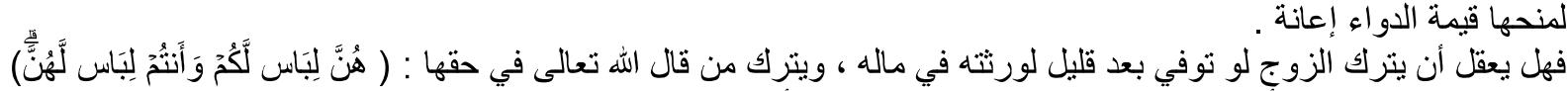

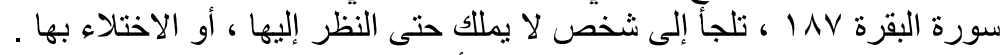

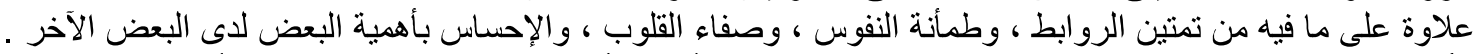

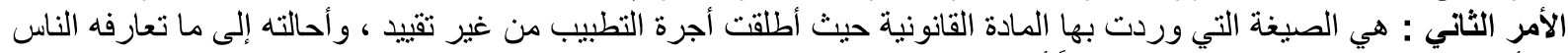

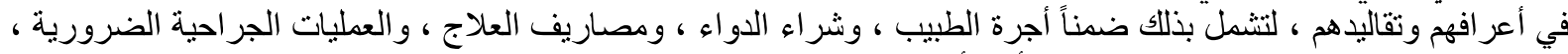

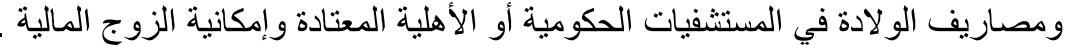

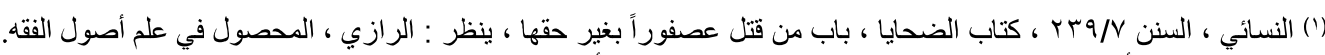

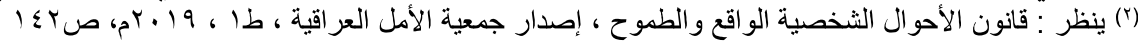

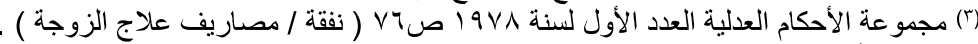

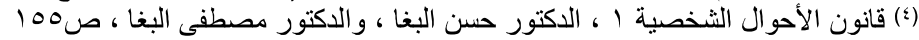

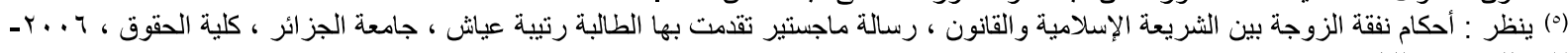

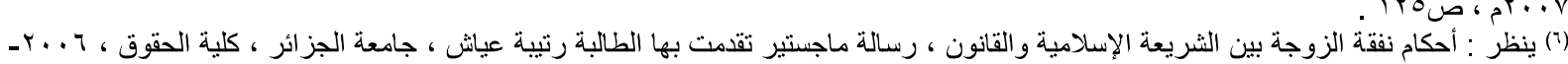

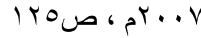

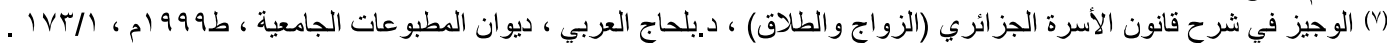




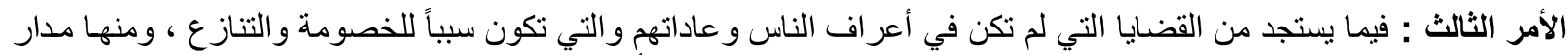

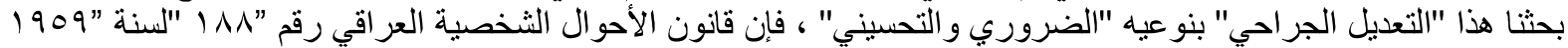

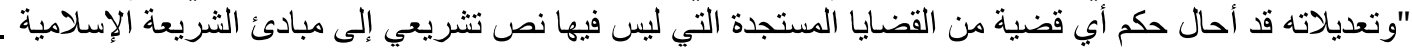

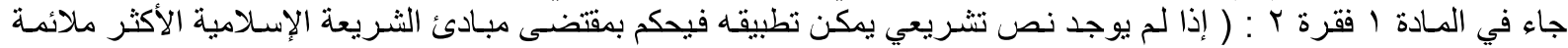

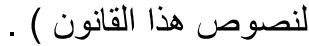

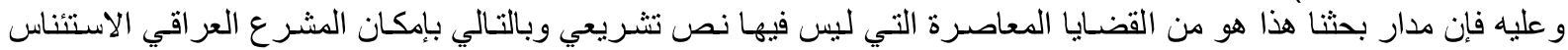

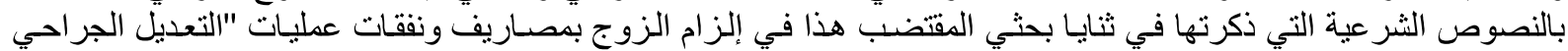

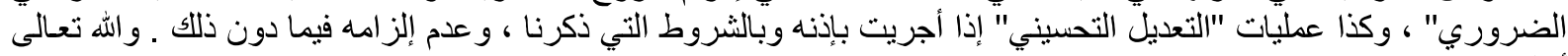

\section{الخاتمة}

أعلم.

الحمد لله رب العالمين ، و أفضل الصلاة وأتم التسليم على سيدنا وحبيينا محمد و على آله وصحبه وسلم تسليماً كثير اً . اتفقى الفقهاء على وجوب النفقة للزوجة على زوجها ، ولكنهم اختلفوا في تفاصيل هذا الموضوع ، ومنه نفقة علاج المر أة ، بين

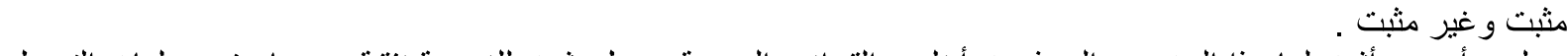
و على رأي من أثبت لها هذا الحق ـ و إليه ذهبت أغلب القوانين العين العربية ـ هل يثبت للزوجة نققة ومصـاريف عمليات التعديل

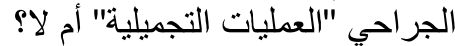
ولإجابة على هذا التساؤل : تقسم نفقات عمليات "التعديل الجراحي" أو "العمليات التجميلية" إلى : نفقة التعديل الجراحي الضروري ، ونفقة التعديل الجراحي

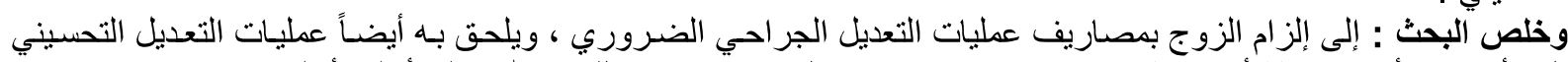

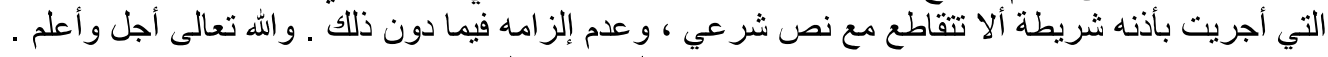
المصادر والمراجع المها دون

أولاً : التقسير

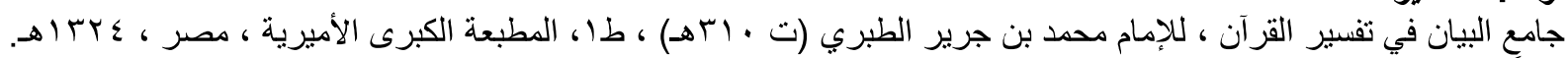

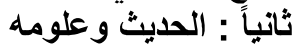
ا ـ صحيح البخاري "الجامع الصحيح" ، للإمام محمد بن إسماعيل البخاري ، مطبعة دار إحياء الكتب العربية لمصطفى البابي الحلبي بمصر البخاري

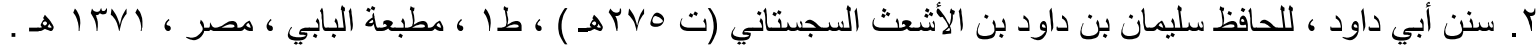

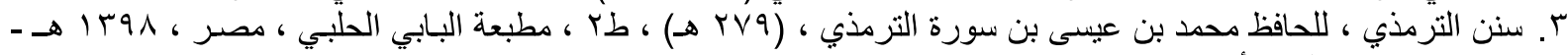

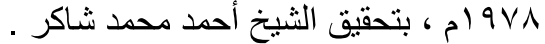

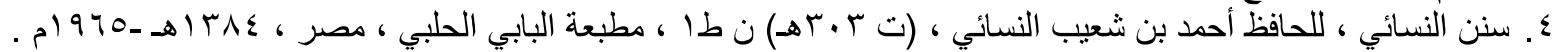

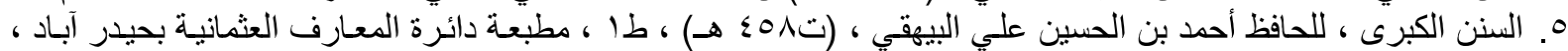

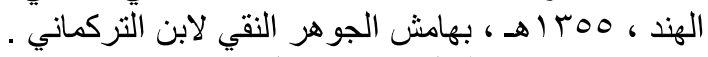

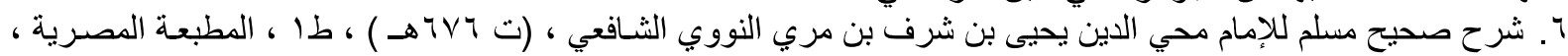

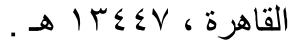

V. فتح الباري بشرح صحيح البخاري ، للحافظ شهاب الدين أحمد بن علي بن محمد بن حجر العسقلاني ، المطبعة الخيريـة ،

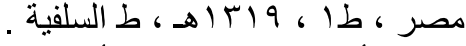

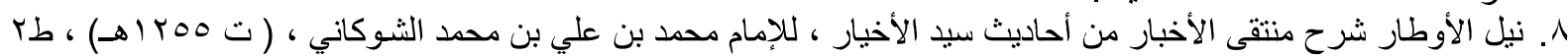

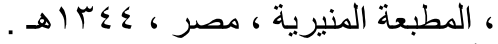

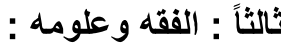

أ. بدائع الصنائع في ترتيب الثرائع ، للإمام علاء الدين أبي بكر بن مسعود الكاسـاني الحنفي ، (ت NVAهـ ) ، طا ، المطبعة

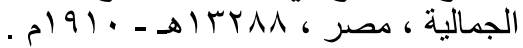

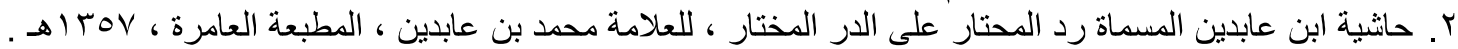

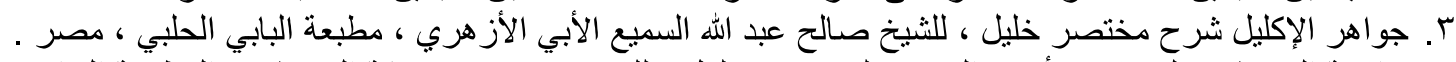

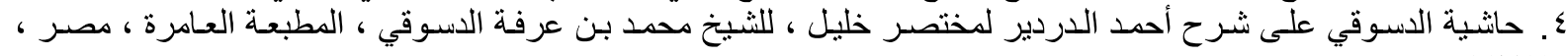
ه I YAV

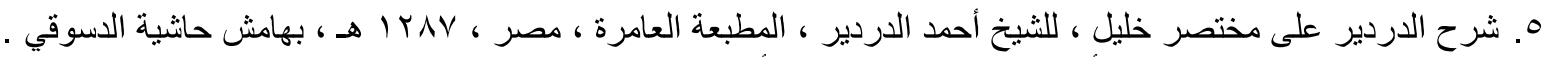

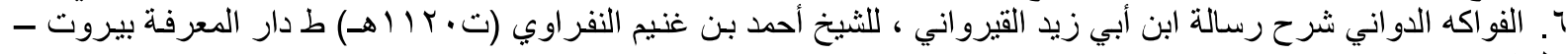

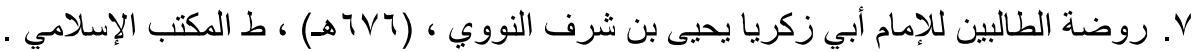

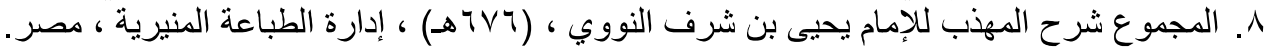




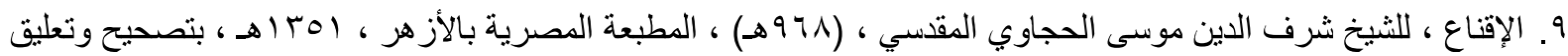

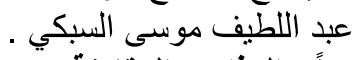

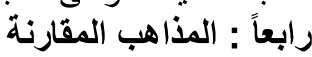

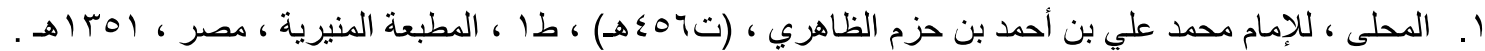

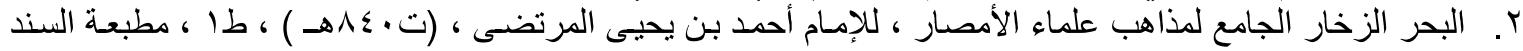

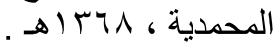

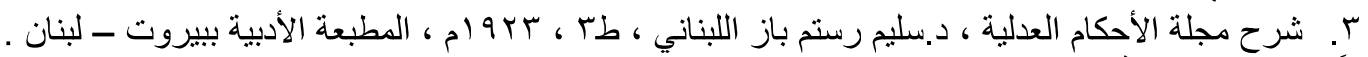

خامساً: : القواعد الفقهية الأنية

ا ـ الأشباه و النظائر في قو اعد وفروع فقه الثافعية ، للإمام جلال الدين عبد الرحمن السيوطي الشافعي ، (1 إوهـ) ، طا ،

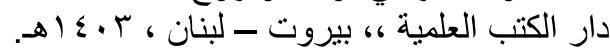

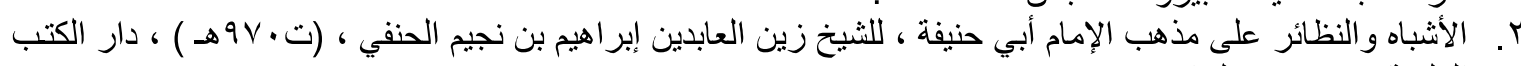

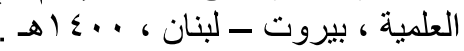

سادساً : الكتب والرسائل

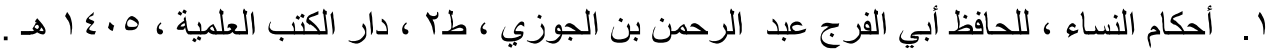

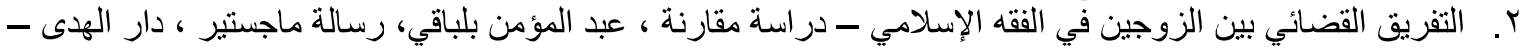

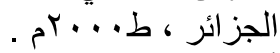

r. أحكام نققة الزوجة بين الثريعة الإسلامية والقانون ، رسالة ماجستير ، رتيبة عياش ، جامعة الجزائر ، كلية الحقوق ،

.

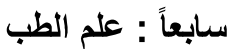

ا ـ. أمر اض ؛ الجهاز البولي والجهاز التناسلي عند الذكور ، د.محد أديب العطل ، د.وليد النحاس ، المطبعة الجديدة دمشق ،

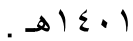

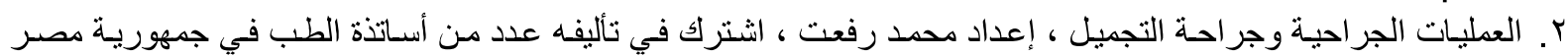

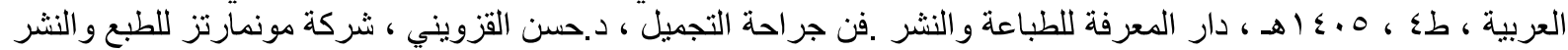
بباريس .

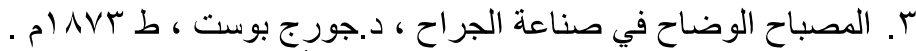

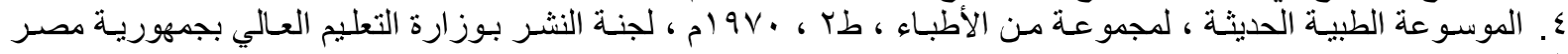

\section{Abstract}

العربية.

The Islamic jurists have agreed that the wife must expense on her husband but they differed in this issue including the expense of the woman's treatment proven and unproven. And according to the opinion of those who have proven the right has gone most Arabs Laws have proven whether the wife has the right of the expenses of the pretion of plastic surgery or not.

I conclude in this research that the husband must pay the expenses of the plastic surgery operations.

Keywords: Surgical Modification, the Islamic jurists, Sharia, Law, husband. 